\title{
LAND SUITABILITY ANALYSIS FOR DECISION-MAKING IN CASSAVA (Manihot Spp.) CULTIVATION IN SOUTHERN PART OF ADAMAWA STATE, NIGERIA
}

\author{
AMBROSE A. ZEMBA, JONAH KEFAS AND ABDULLAHI HAMZA
}

(Received 18 August 2016; Revision Accepted 8 September 2016)

\begin{abstract}
This study assessed the physical land suitability for cassava cultivation in southern part of Adamawa State using Multi-criteria evaluation and GIS technique. Within the study area, the production of cassava is mainly for food and there are only little opportunities for its commercial development. Therefore it is necessary to carry out land suitability analysis in order to provide information on the study area that would guide in sustaining long term production of cassava on commercial basis. The environmental variables examined were Mean Annual rainfall, Mean Temperature, Length of rainfall, Relief and Soil. The primary data were sourced by means of field survey to obtain the coordinates of the current cassava growing areas for mapping. The five factor maps were reclassified based on environmental requirement of cassava crop in the IDRISI Taiga environment and different weights were assigned to each factor to represent their relative importance using the pair-wise comparison matrix. The result, which is explicitly revealed on a single map, indicates that the areas that are suitable for cassava cultivation constitutes $65.92 \%$ while those that are not suitable amounts to $34.08 \%$. Similarly, the current cassava growing areas were mapped and the areas identified are Dissol, Mbulo, Maitani, Farang, Timdore and Wadore which fell within the suitable category. The study therefore recommends that cassava production should be encouraged among farmers so as to utilize the proportion of land area found to be suitable for cassava production in Southern Adamawa State.
\end{abstract}

KEYWORDS: Land suitability, Cassava cultivation, Multi-criteria evaluation, Pair-wise Comparison Matrix, IDRISI Taiga

\section{INTRODUCTION}

Crop-land suitability analysis is a prerequisite to achieving optimum utilization of the available land resources for sustainable agricultural production. One of the most burning needs in both developed and developing nations is to improve agricultural land management and to impart suitable cropping patterns in order to increase agricultural production with efficient use of land resources (Perveen et al., 2007). Hence, comprehensive reliable and timely information on agricultural resources is necessary for Nigeria where agricultural potential of the land resources is being pressurized by high population growth and environmental hazard like drought and soil erosion. On the other hand, Nigeria has been faced with food supply deficiency which has almost become an intractable problem in the past decades (Mathias, 2014). This situation is highly pronounced in urban areas due to high population density with agricultural land being frequently in short supply compare to more mouths to be fed. In order to meet the increasing demand for food, the farming community has to increase production so as to meet the growing demand of the growing population (Venkatatnan and Ravishankar, 2010).

However, Nigerian soils have a substantial agricultural potential but a fundamental constraint to its development is the unreliable method of data acquisition and management on agricultural land (Joshua et al, 2013). The consequence is poor knowledge and unreliable data for agricultural planning. In addition, the use of land is not only determined by the user but also the land suitability which is governed by different land attributes such as the soil types, underlying geology, topography and hydrology (FAO, 1993). These attributes can limit the extent of land available for various purposes. To get the maximum benefit out of the land, its proper use within the context of suitability is inevitable. In Nigeria however, the productivity of soil is decreasing because lands have been utilized for all purposes at the expense of their suitability thereby resulting in land degradation (Senjobi, 2007).

In view of the above, the importance of cassava (Manihot spp.) in mitigating hunger and providing food security is timely and cannot be over emphasized. Its food security features have attracted interest for some time and being known to be common within the tropical environment that cassava has the potential to combat hunger and address food security issues (Harvest Plus, 2012). Hence, the suitable areas for agricultural use are determined by an evaluation of the climate, soil, topography as well as understanding of local biophysical

Ambrose A. Zemba, Department of Geography, Modibbo Adama University of Technology, P.M.B. 2076 Yola, Adamawa State, Nigeria.

Jonah Kefas, Department of Geography, Concordia College, P.M.B. 2031 Yola, Adamawa State, Nigeria. Abdullahi Hamza, Department of Geography, Concordia College, P.M.B. 2031 Yola, Adamawa State, Nigeria. 
restraints. But where many variables of this nature are involved, Geographic Information System (GIS) technology offers a dynamic tool for multidimensional process of land use evaluation with a powerful tool for geo-environmental analysis (Jensen and Rietveld, 1990; Pereira \& Duckstein, 1993; Perveen et al, 2007). It allows the user to integrate database generated from various sources and analyze them efficiently in a spatiotemporal domain by overlaying different map layers.

1. Within the study area the demand for cassavarelated products are on the increase but its production is basically for food. Hence, more areas of cassava cultivation need to be discovered so as to attract investors in the commercialization of cassava in this region. Thus, in mapping out the distribution of major food crops in Adamawa state, Sajo \& Kadams (1999), posited that the southern agricultural zone of Adamawa state receives annual rainfall of $1400 \mathrm{~mm}$ and is therefore important for root and tuber crops. Land suitability is however not determined by single environmental factor, but the collection and analysis of information which may have significant influence on the use that can be made of the soil (Joshua et al, 2013). Moreover, the study of how the combination of these environmental factors affect the cultivation of cassava has never been delved into within the study area. This therefore makes it necessary to carry out land suitability analysis in order to unravel its suitability and capability for sustaining long term production of cassava in southern part of Adamawa State. The objectives of the study include to: determine the extent of land area suitable for cassava cultivation in the study area; identify and map out areas currently producing cassava within the study area; and provide a decision making guide for the current and potential farmers of cassava within the study area using GIS.

\section{THE STUDY AREA AND METHODOLOGY}

\subsection{The Study Area}

The study area is located between Latitude $7^{\circ} 0^{\prime}$ to $9^{\circ} 0^{\prime} \mathrm{N}$ and Longitude $11^{\circ} \mathrm{O}^{\prime}$ to $13^{\circ} \mathrm{O}^{\prime} \mathrm{E}$. It has a total landmass of $10602.95 \mathrm{~km}^{2}$ with a population of 507047 people (projected from 2006 Census to 2015). It comprises of Jada, Ganye and Toungo Local Government Areas of Adamawa State. It is bounded by Mayo-Belwa and Fufore Local Government Areas to the north, the Cameroon Republic to the eastern side and Taraba state borders the area to the South and West as shown in Figure 1.

The movement of the Inter Tropical Discontinuity (ITD) and altitude are the basic elements controlling rainfall distribution in the study area. Rainfall decreases from the south $(1600 \mathrm{~mm})$ towards the north $(900 \mathrm{~mm})$ within the study area. The mean onset date for rainfall within the study area is around $10^{\text {th }}$ April while the cessation date is approximately $6^{\text {th }}$ November. The temperature is high throughout the year because of the incoming radiation with a sharp drop at the onset of rains due to the effect of cloudiness. The maximum temperature usually occurs in April to about $38^{\circ} \mathrm{C}$ while the minimum temperature can be as low as $15^{\circ} \mathrm{C}$ between December and January (Adebayo, 1999).

Geologically, the study area falls within the eastern extension of the Nigerian Precambrian rocks. It has several high-level plateau surfaces which are part of discontinued mountain ranges. The most striking landform feature in the area is the mountain ranges, which in most cases appear as grouped hills and generally, trending from north to south particularly along the eastern border lands of Nigeria with Cameroon. The most popular of these ranges is the Alantika and the Mangia hills south-west of Jada (Tukur, 1999). The soil was derived from a soil survey of a former Gongola state under different map units, ranging from units 201-242. The soils include luvisols, lithosols, combisols and vertisols. These soils have different characteristics ranging from high base saturation, deep and well drained, high organic matter content, low to moderate saturation, poorly drained and dark colored among others (Ray, 1999).

\subsection{Data Types and Sources}

The physical parameters (factors) directly related to cassava crop production were considered for analysis. These factors include relief, soil, annual rainfall, length of rainy days and temperature of the study area. Primary data types were collected from the field by means of physical observation as well as picking of geographic coordinates of the current areas of cassava cultivation using the Global Positioning System (GPS). The secondary data, which were basically concerned with the five factor maps were generated from data obtained from the Upper Benue River Development Authority, Yola in 2014.

\subsection{Data Processing}

The five parameters (annual rainfall, annual rainfall length, air temperature, soil and relief maps) were geo-referenced by transforming their LATLON to Universal Transverse Mercator (UTM) coordinate System in the ArcGIS 10.2. The ' $X$ ' and ' $Y$ ' minimum and maximum values of the coordinates were used to create map boundary. The LATLON of the tie-points were inserted one after the other to ensure the true coordinates of these points. After geo-referencing, the maps were re-sampled in order to take their exact cell size as well as to enable the overlay process. The resampled maps were later digitized and saved as project map which were imported to Idrisi Taiga for overlay analysis. The maps (Fig 2, 3, 4, 5 and 6) were prepared in ArcGIS 10.2 software representing the environmental variables that constitute the elements of the multicriteria used. 


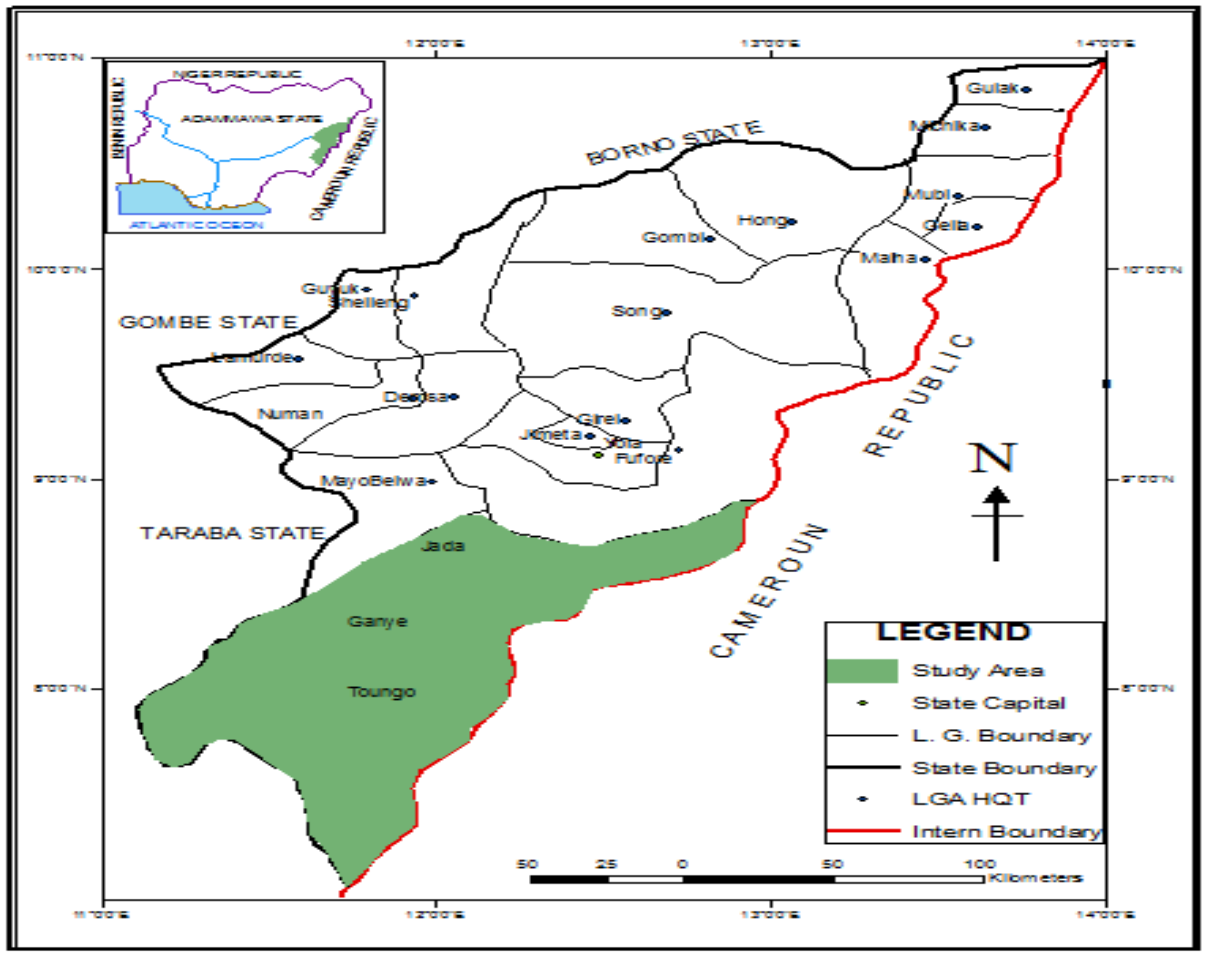

Figure 1: The Study Area

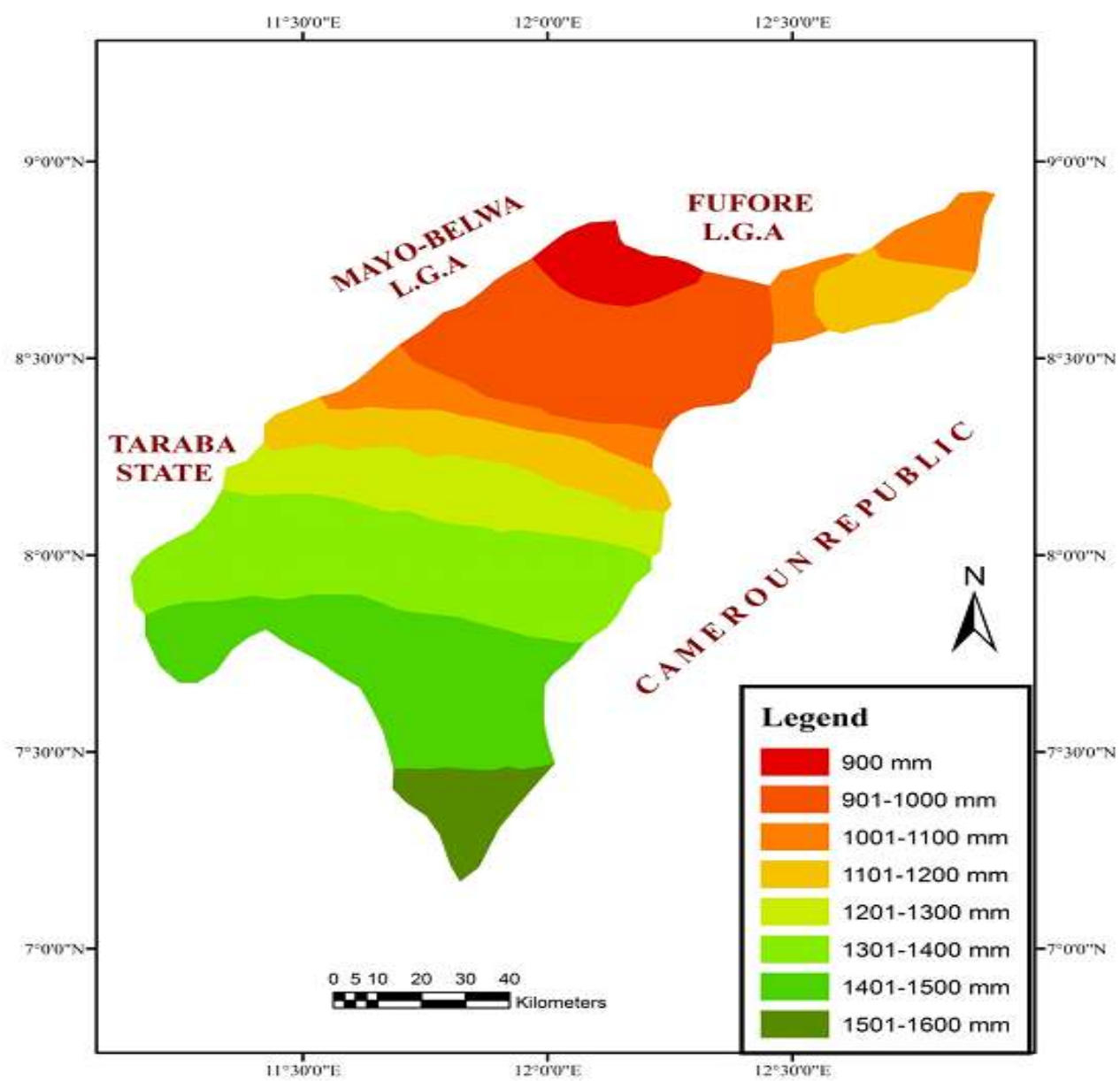

Figure 2: Mean Annual Rainfall Map of the Study Area 


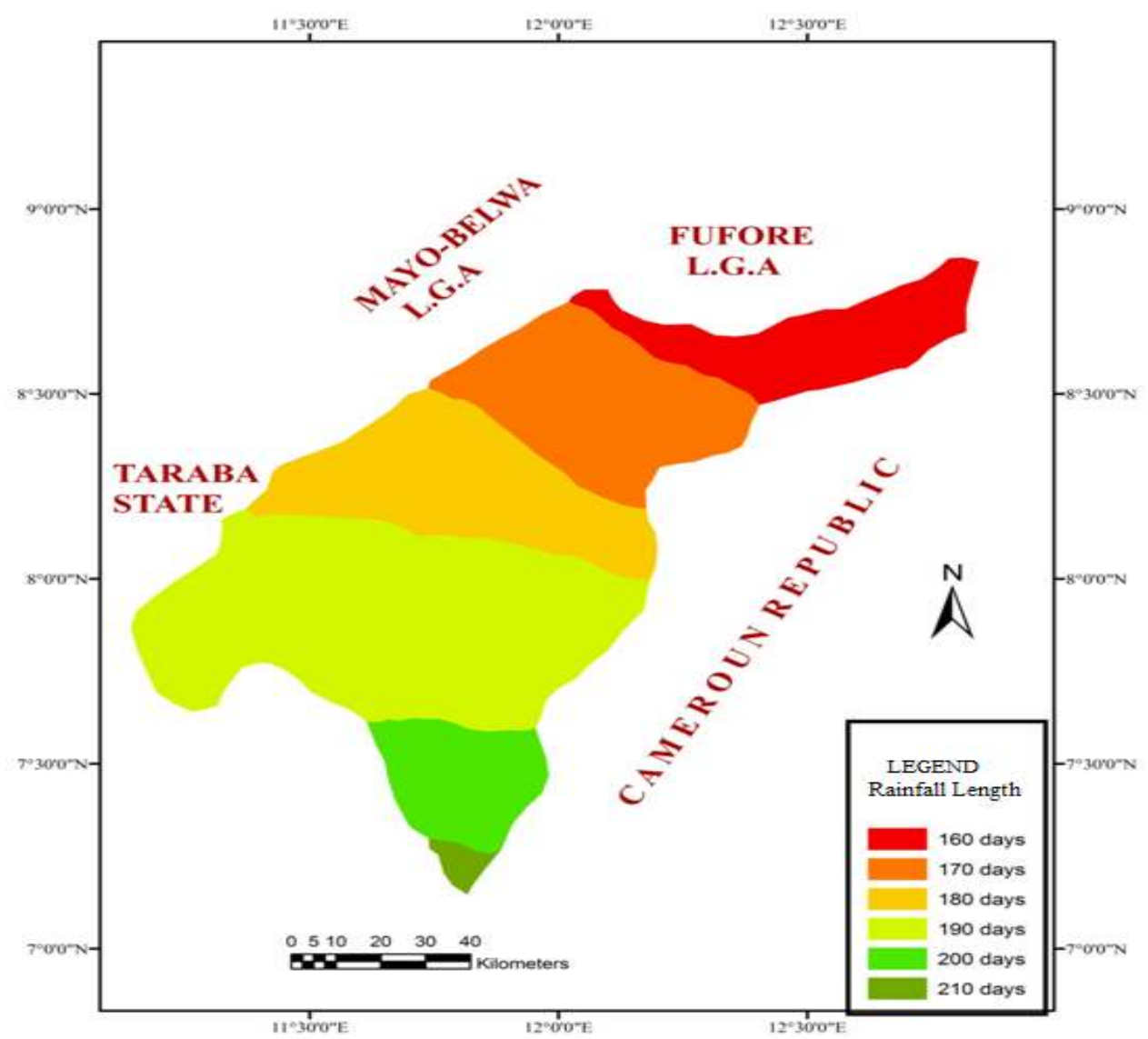

Figure 3: Mean Length of Rainfall of the Study Area

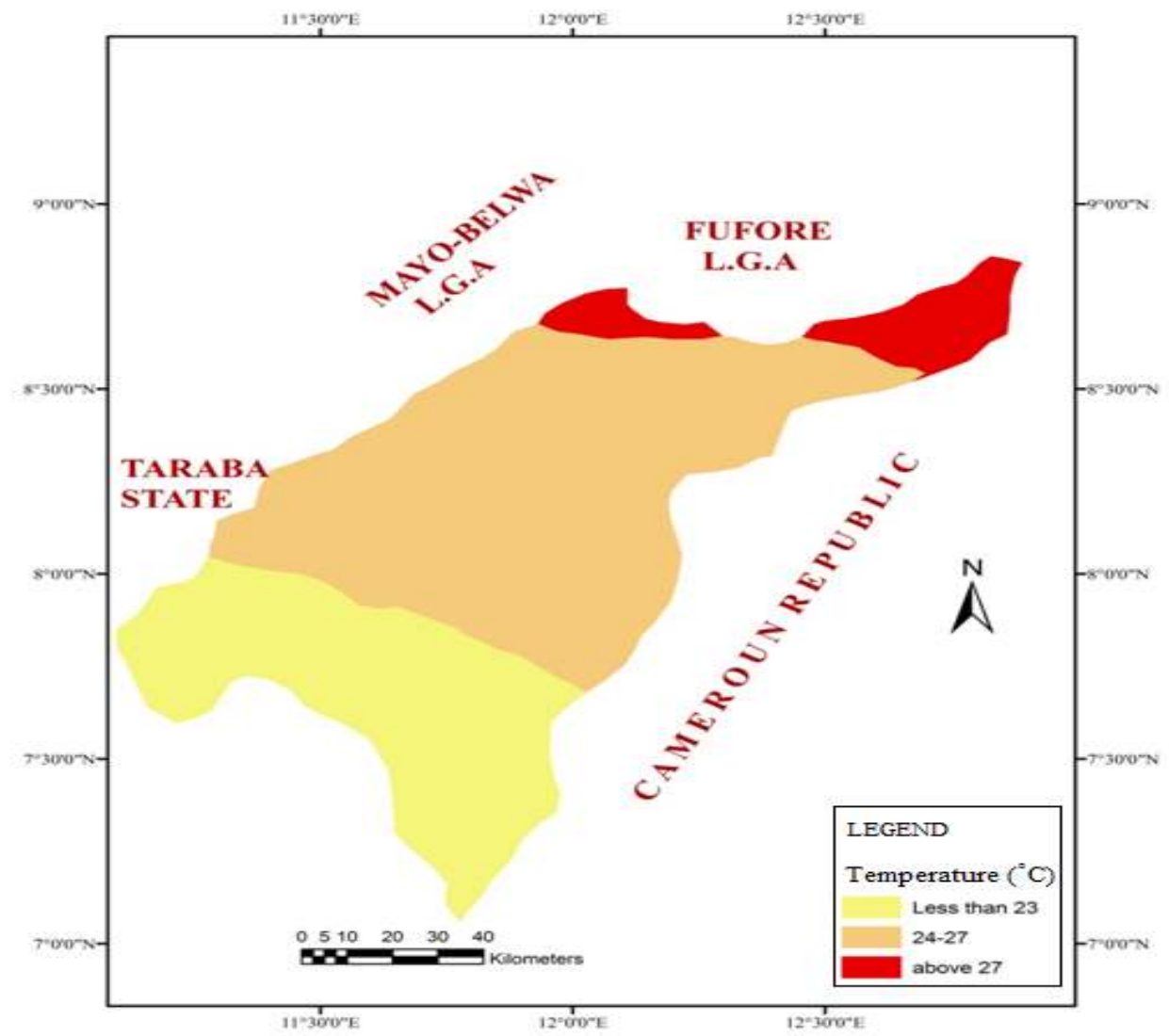

Figure 4: Mean Temperature Map of the Study Area 


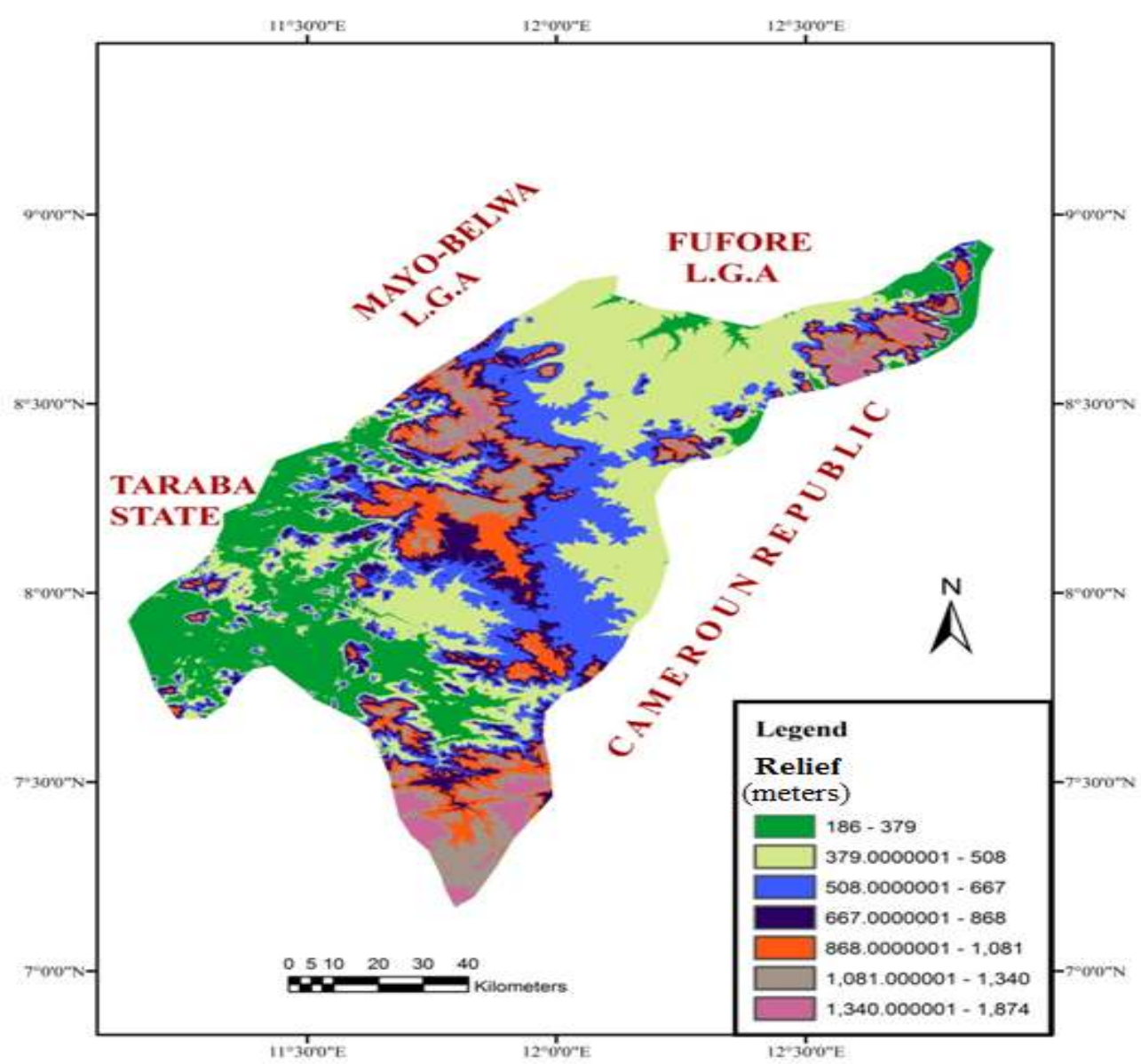

Figure 5: Relief Map of the Study Area

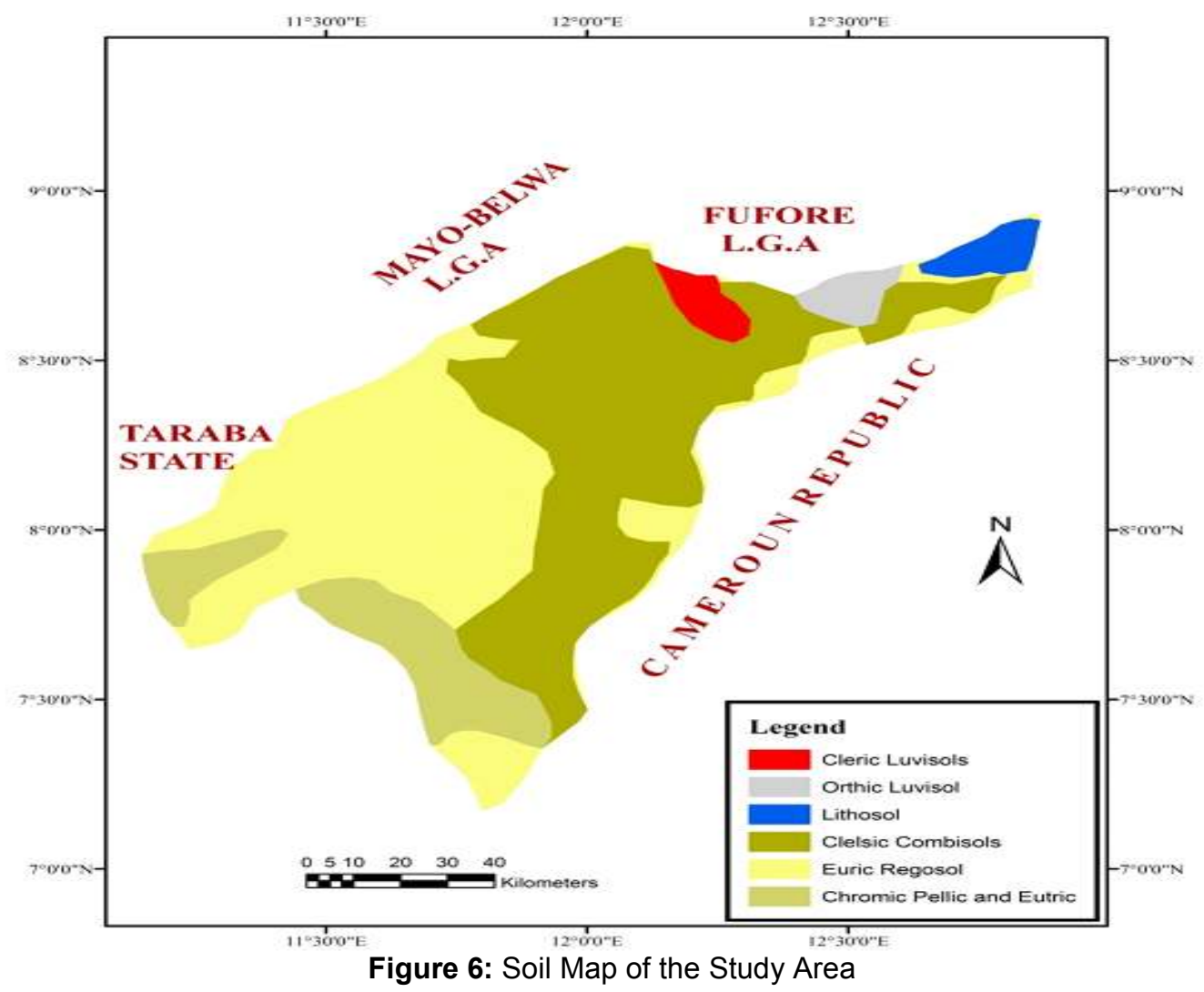




\section{$2.4 \quad$ Data Analysis}

The map algebra (overlay) method of analysis using GIS was employed for data analysis. This involved combination of information from one GIS layer with another to derive an attribute for both of the layers. This overlay or spatial join was able to integrate data of different types such as soils, relief, rainfall, temperature and other data available for analysis (Samuel, 2014). Hence, the suitability criteria for cassava production were defined on the basis of literature reviews and experts knowledge as presented in Table 1.

Table 1: Criteria Definition of Environmental Factors for Cassava Cultivation

\begin{tabular}{ll}
\hline Factors & Criteria \\
\hline Rainfall length & $\geq 107$ rainy days \\
Annual rainfall & $1000-2000 \mathrm{~mm}$ \\
Temperature & $\leq 27^{\circ} \mathrm{C}$ \\
Relief & $150-1000 \mathrm{~m}$. \\
Soil & Light sandy loams \\
\hline
\end{tabular}

Source: USDA (1997); Adjei and Owuraku, 2012

\subsection{Assigning Criteria Weights}

Different weights were assigned to each factor to represent their relative importance using the pair-wise comparison analysis developed by Saaty (1990). The purpose of the criteria weighting was to express the importance of each criterion relative to other criteria in determining the suitability for cassava growing sites. The more important criterion had the greater weight in the overall evaluation as presented in Table 2. Finally the weighted criteria were processed to generate the composite suitability map. This method of analysis was selected because it allows the decision makers to assign different levels of importance to the different factors involved in land suitability (Qiu et al, 2013).

After applying the Analytic Hierarchy Process (AHP) generated weights in the data, the additional subroutine (overlay modules) of IDRISI Taiga using image calculator was used for the analysis. The process involves the summation of a continuous multiplication of each criterion by its weight e.g. (Temperature $\times 0.480)+$ (Rainfall Length $\times 0.194)+($ Soil $\times 0.156)+($ Annual rainfall $\times 0.124)+($ Relief $\times 0.046)$. This process was carried out in order to produce a fuzzy suitability map which was later reclassified to produce the cassava suitability map.

Table 2: Weighting Criteria by Pair-wise Comparison

\begin{tabular}{llllll}
\hline Criteria & Temperature & $\begin{array}{l}\text { Rainfall } \\
\text { length }\end{array}$ & Soil & $\begin{array}{l}\text { Annual } \\
\text { rainfall }\end{array}$ & Relief \\
\hline Temperature & 1 & 5 & 5 & 7 & 3 \\
Annual rainfall & $1 / 5$ & 1 & 1 & 5 & $1 / 3$ \\
Rainfall length & $1 / 5$ & 1 & 1 & 5 & 3 \\
Relief & $1 / 7$ & $1 / 5$ & $1 / 5$ & 1 & $1 / 3$ \\
Soil & $1 / 3$ & 3 & $1 / 3$ & 1 & 1 \\
\hline
\end{tabular}

Source: Adapted from Saaty, (1990)

\subsection{Criteria Standardization}

Calculating factor weights had a crucial role in production of cassava suitability map. The weights of the five criteria used for the analysis were calculated. Firstly, the values in the pair-wise matrix were converted to decimals and the sum of each column was obtained. Each value in the pair-wise matrix was later divided by the sum of its column to arrive at the values presented in Table 3. To get the weight of each criterion, the mean of each row was determined, which was later divided by column sum. For instance, temperature weight was computed by dividing the row total for temperature (2.40) by the sum of row totals $(2.40+0.62+0.97+$ $0.23+0.78)=0.480$.

This is mathematically expressed as:

Temperature weight $=2.40 /(2.40+0.62+0.97+0.23$ $+0.78)=0.480$. This process was also applied for rainfall length, annual rainfall, soil and relief as seen in the normalized matrix. Hence, these weights became normalized; their sum equals 1 (Table 3 ). 
Table 3: A Normalized Comparison Matrix for Cassava Production

\begin{tabular}{lllllllll}
\hline Criteria & Temperature & $\begin{array}{l}\text { Rainfall } \\
\text { length }\end{array}$ & Soil & $\begin{array}{l}\text { Annual } \\
\text { rainfall }\end{array}$ & Relief & Total & $\begin{array}{c}\text { Criteria weight } \\
\text { (mean of rows) }\end{array}$ & $(\%)$ \\
\hline Temperature & 0.53 & 0.49 & 0.66 & 0.33 & 0.39 & 2.40 & 0.480 & 48.0 \\
Annual rainfall & 0.11 & 0.10 & 0.13 & 0.24 & 0.04 & 0.62 & 0.124 & 12.4 \\
Rainfall length & 0.11 & 0.10 & 0.13 & 0.24 & 0.39 & 0.97 & 0.194 & 19.4 \\
Relief & 0.07 & 0.02 & 0.04 & 0.05 & 0.05 & 0.23 & 0.046 & 4.6 \\
Soil & 0.18 & 0.29 & 0.04 & 0.14 & 0.13 & 0.78 & 0.156 & 15.6 \\
Total & 1 & 1 & 1 & 1 & 1 & 5.00 & 1 & 100 \\
\hline
\end{tabular}

Source: Adapted from Saaty, (1990)

\subsection{Map Algebra}

After applying the AHP generated weights in the data, the additional subroutine (overlay modules) of IDRISI Taiga using image calculator was used for the analysis. This is because the calculator-like interface of the IDRISI Taiga provides a set of mathematical tools necessary for complete map algebra. The process involves the summation of a continuous multiplication of each criterion by its weight (Temperature $\times 0.480)+$ (Rainfall Length $\times 0.194)+($ Soil $\times 0.156)+($ Annual rainfall $\times 0.124)+($ Relief $\times 0.046)$. This process was carried out in order to produce a fuzzy suitability map. The resulting fuzzy map was later reclassified to produce the cassava suitability map.

\subsection{Defining Suitability Classes for Mapping Cassava Suitable Areas}

To arrive at the final suitability map, the resulting fuzzy map was reclassified and the suitable site for cassava cultivation on the composite map is concerned with areas that met the five (5) criteria for cassava suitability evaluation. Any area that fails to meet one of the five criteria was considered not suitable for cassava cultivation (fuzzy concept). This means that areas that met less than five requirements were considered as not suitable for cassava cultivation whereas places that were considered suitable for cassava cultivation on the composite map are those that met the requirement of the five factors considered for the analysis. Thus, two classes of suitability for cassava cultivation were derived from the algebra based on the fuzzy concept.

The processes of mapping out current areas producing cassava in the study area were carried out in ArcGIS environment by inserting the coordinates of the identified cassava production areas on a geo-referenced and digitized map of the study area. This process explicitly shows the distribution of the current cassava production areas on the map of the study location.

\section{RESULTS AND DISCUSSION}

\subsection{Land Suitability for Cassava Cultivation in the Study Area}

To assess whether or not the five variables are suitable for cassava cultivation, the land suitability order by FAO (1993) was adopted which indicates in a simplest form whether land is suitable (S) or not suitable (NS) for the specified use. Hence, the overall suitable area for cassava cultivation covers $6989.46 \mathrm{~km}^{2}$
(65.92\%), whereas about $3613.49 \mathrm{~km}^{2}(34.08 \%)$ of the study area falls within the unsuitable area (Figure 7).

The "suitable area" which is mostly in the central part although, cutting across the three Local Governments of the study location covers the largest portion of the map with a total area of $6989.46 \mathrm{~km}^{2}$ $(65.92 \%)$. This area has satisfied the requirements of the five variables used in the analysis and one of the reasons for such is attributed to the good soils of the region which is mostly loamy sands. These soils are well drained, moist and fertile with light to medium textures such as sandy loam, silt loam and clay loam (Ray, 1999). Such fertile soils tend to have a deep horizon that is friable enough to allow the development of the tubers (Cassava Production Guidelines, 2010). The Mean Rainfall of more than $1500 \mathrm{~mm}$ with up to 200 days of rainfall is another factor that supports the growth of cassava at all levels within the study location. The rainfall amount and duration is sufficient enough to give support during the critical period in cassava growth which is between 30 to 150 days after planting (Cassava Production Guidelines, 2010). The Mean Temperature of the study area within the Suitable (S) category has a considerable effect on cassava production. According to Alves et al (2000), the highest root production for cassava crop can be expected in the tropics where temperature average $25-27^{\circ} \mathrm{C}$ which corresponds with the condition obtainable in most part of the study location.

The unsuitable area includes places in the western and eastern border, the extreme south and the north-eastern part, with some traces in the central part of the study area. In this part of the study location Relief, Temperature and Mean Annual Rainfall are responsible for the unsuitable category as they tend not to meet the environmental requirements for cassava production hence, fell outside the suitability range for cassava cultivation.

Firstly, the striking landform features of the Atlantika, Verre and Shebshi Mountain ranges which are evident within the unsuitable area can inhibit the growth of cassava especially at the root development stage. This corresponds with recommendations of the Guidelines by Nawaz and Mahaz (2014) that cassava does not perform well with elevation exceeding 1000 meters above sea level. The Atlantika Mountain (1000$1400 \mathrm{~m}$ ) East of Ganye and Jada forms a natural boundary between Nigeria and Cameroun. The Shebshi mountain range (highest elevation 2,042m.) is South of 
Ganye and the Verre hills are found East of Jada (Tukur, 1999). Soils on this platform can pose a limiting factor that can lead to scanty growth potential of cassava crop (Ray, 1999).

Mean Annual Rainfall is another factor responsible for the unsuitable nature of land for cassava production. This is because the northern part of the study area with less than $1000 \mathrm{~mm}$ of rainfall has fallen out of suitability range for cassava production. This assessment is imperative because cassava responds to water deficiency at different levels of developmentmorphological, physiological, cellular and metabolic (Augusto, 2002). For instance, cassava responds to water deficiency by rapidly reducing its evaporating leaf area and partially closing the stomata (Vincent, 2009). The reduction in storage root yield depends on the duration of the water deficit and is determined by the sensitivity of a particular growth stage to water stress.

The temperature condition in some part of the study area is above $27^{\circ} \mathrm{C}$ which is beyond the suitability range of temperature for cassava production. This will have negative effects on cassava growth because temperature affects sprouting, leaf formation, leaf size and storage root formation.

As stated earlier, an experiment was conducted during this research. This involves identifying some cassava farms and taking their coordinates. The areas currently under cassava cultivation have been depicted. The essence is to determine whether or not they match with the suitable growing areas as revealed by this study. Thus, the areas identified as the current cassava cultivation areas at the time of investigation include Maitani, Dissol, Timdore, Wadore, Mbulo and Farang. The study therefore reveals that all the six areas identified fell within the suitable area of cassava cultivation. Thus, the study agrees with the postulations of Sajo and Kadams (1999) that the southern agricultural zone of Adamawa state receives an annual rainfall of $1400 \mathrm{~mm}$ is therefore important for root and tuber crops.

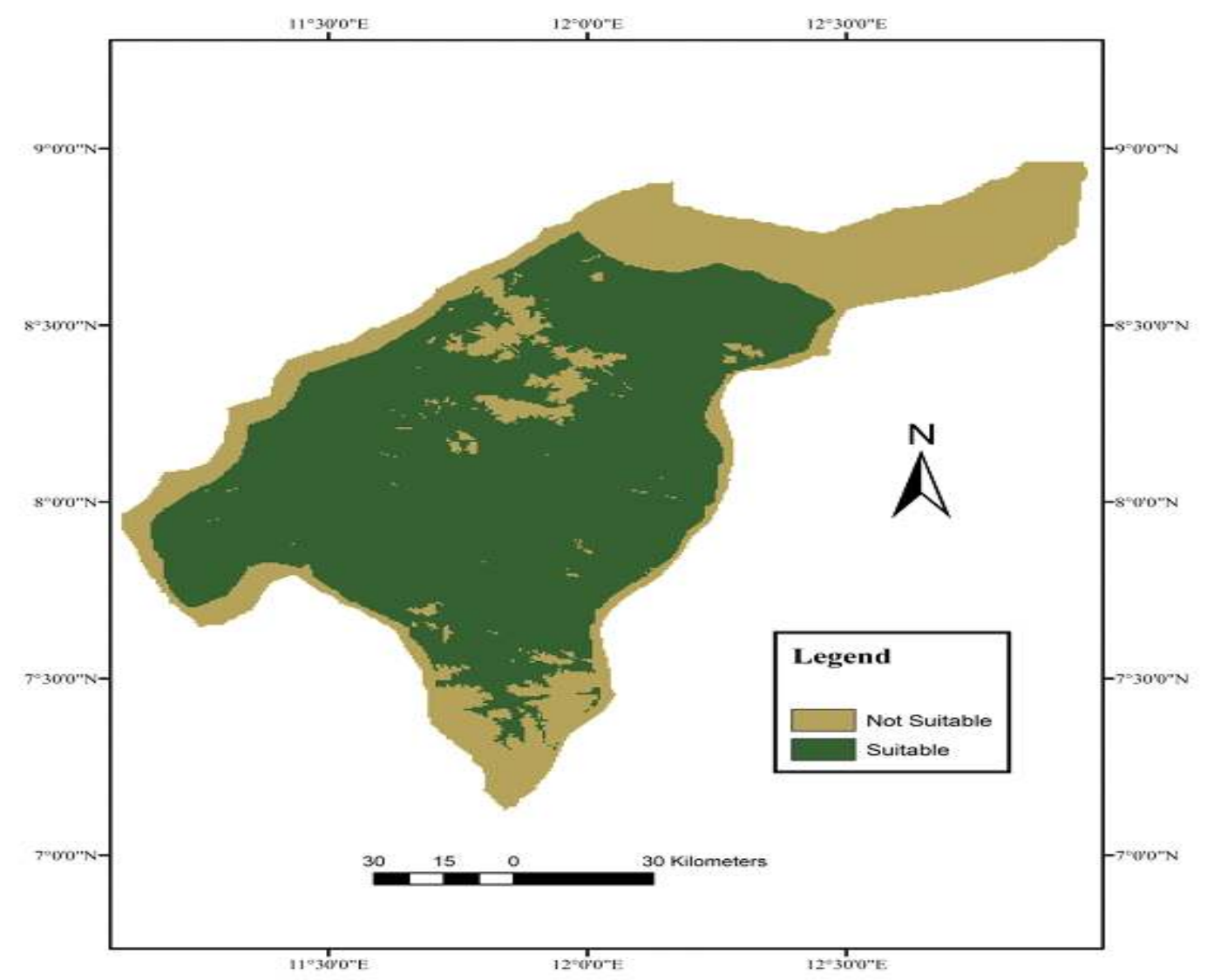

Figure 7: Suitability Map of Land Areas for Cultivation of Cassava in the study Area

\subsection{Decision Making Guide for Current and Potential Farmers of Cassava}

Beside the general suitability evaluation, individual criterion for securing agricultural land use plays an important role. This is because calculation of relative weights of factors for the production of cassava was based on the expert opinion and local knowledge obtained from field surveying. It was found that the highest weights were assigned to temperature and length of rainfall. Soil and annual rainfall were also found effective while relief was identified as the least important factor to be considered in cassava crop suitability.

Temperature is the most important factor because sprouting of the stem cutting in cassava often has a temperature range within which it germinates, and they will not do so above or below such range (George and Rice, 2000). At low temperatures of e.g. $16^{\circ} \mathrm{C}$, sprouting of the stem cutting is delayed and the rate of leaf production is decreased. Sprouting is hastened when the temperature increases up to $30^{\circ} \mathrm{C}$ but is 
inhibited with temperatures greater than $37^{\circ} \mathrm{C}$ (Augusto, 2002).

After germination, rapid growth of cassava results in a high demand for light and moisture especially during the first critical stage. Matured seed need to take in significant amount of water before growth can resume. In addition, exposure to prolonged length of rainfall is required to shorten the length of dormancy in cassava growth and development.

The not suitable category includes mountainous areas of the region at high degree of physical limitation which could not be easily overcome. It is therefore not economical to put such land under production. Such a qualitative evaluation is to help decision makers (local farmers and agricultural development institutes) to select the most appropriate site for cassava cultivation.

Comparison of the present land use for cassava cultivation with the analyzed suitability classes was conducted to examine the degree of mismatch. It was noted that the "suitable class" has no constraint as all the identified areas of current cassava cultivation fell within the said category.

\section{CONCLUSION}

In this study, Multi Criteria Evaluation with GIS technique was applied to identify suitable areas for cassava cultivation in Southern Adamawa State. The result obtained from the study indicates that GIS technique could provide a superior guide map for decision makers which could be used to consider crop substitution in order to achieve better agricultural production. The study clearly brought out areas suitable for cassava cultivation which was derived from the five criteria maps. These maps were analysed within the context of GIS after a pair-wise comparison of each factor relative to the other. Many inputs into the GIS based land suitability evaluation are the maps of the criteria (mean annual rainfall map, annual rainfall length map, air temperature map, soil map, and relief map) which represent the complex information in a simple classified map.

\section{RECOMMENDATIONS}

Based on the findings of this study, the following recommendations are made:

i. Potential cassava farmers should allocate their resources in ensuring that the $65.92 \%$ of the total landmass suitable for cassava production is well utilized whereas, the "not suitable" category for the said crop should be allocated to other crops.

ii. Agricultural Development Agencies should provide loans for potential cassava farmers so as to encourage abundant supply of cassava.

iii. Resource planners and decision makers should rely on this assessment so as to avoid the complex problem that involves subjective assessments with multiple criteria.

\section{REFERENCES}

Adebayo, A. A., 1999. Climate. In Adebayo A. A. and Tukur A.L. Eds. Adamawa State in Maps Paraclete Publishers, Yola, Nigeria, 23-26.
Adjei, $\mathrm{N}$ and Owuraku, S., 2012. Promoting cassava as an industrial crop in Ghana: effects on soil fertility and farming system sustainability. Applied and environmental science journals volume 2012, article ID 940954, 8.

Alves, A. A. C and Setter, T. L., 2000. Response of cassava to water deficit: leaf area growth and abscisic acid. Crop Science 40, 131-137.

Augusto, L., Ranger, J., Binkley, D., Rothe, A., 2002. Impact of Several Common Tree Species of European Temperate Forests on Soil Fertility Ann. For. Sci. 59, 233-253.

Cassava Production Guideline., 2010. Department of Agriculture, Forestry and Fisheries, Agricultural Information Sciences, Pretoria.

FAO, 1993. Guideline for land-use Planning Rome, Italy.

George, M and Rice, K., 2000. Range Plant Growth \& Development Research 7 Extension Centre, University of California, October, $23^{\text {rd. }}$

Harvest Plus., 2012. Working on Biofortification Programs Annual Report, This Report Focused on Four Highlights of the Organism In 2012, Published July 2, 2013.

Janssen, R. and Rietveld, P., 1990. Multi-criteria Analysis and GIS: An Application to Agriculture Land Use in the Netherlands.

Joshua, J. K., Anyanwu, N. C and Ahmed, A. J., 2013. Land Suitability Analysis for Agricultural Planning Using GIS and Multi-Criteria Decision, International Journal of Applied Research and Studies Vol. 2:22.

Mathias, E. Z., 2014. Land Suitability Analysis for Wheat crop in Adamawa State Msc. Thesis, Adamawa State University, Mubi-Nigeria, 89.

National Population Commission., 2006. Population Census of the Federal Republic of Nigeria.

Nawaz, M. S and Mahaz, M. K., 2014. Land Suitability Analysis for Sustainable Agricultural Land-use Planning, International Journal of Scientific \& Research Publications, vol.4, issue 3, March, 2014.

Pereira, J. M and Duckstein, L., 1993. A multiple criteria decision-making approach to GIS based Land suitability evaluation International Journal of Geographical Information Science 7, (5): 2.

Perveen, F., Nagasawa, R., Uddin, I and Delowar Hossain, K. M., 2007. Crop land suitability Analysis using a multi-criteria evaluation and GIS approach, $5^{\text {th }}$ International Symposium on Digital Earth. The University of California, Berkeley, USA: p. 18, 2007. 
Qiu, F., Chastain, B., Zhou, Y., Zhang, C and Shridhan, H., 2013. Vulnerability Mapping Analysis Using Fuzzy in West Africa.

Ray, H. H., 1999. Soils and erosion. In Adebayo A. A. and Tukur A.L. Eds. Adamawa State in Maps. Paraclete Publishers, Yola, Nigeria, pp 27-29.

Saaty, T. L., 1990. How to make a decision: The analytic hierarchy process, European Journal of Operational Research 48, 9-26.

Sajo, A. A and Kadams, A. M., 1999. Food and cash crops: zonal crop distribution In A.A. Adebayo \& A.L. Tukur (eds.), Adamawa State in Maps $1^{\text {st }}$ edition, pp37 Paraclete publishers, Yola-Nigeria

Senajobi, B. A., 2007. Comparative Assessment of the Effect of Land use and Land type on Soil Degradation and Productivity in Ogun State, Nigeria PhD Thesis University of Ibadan.

Tukur, A. L., 1999. Landforms In: Adebayo A. A. and Tukur A.L. Eds. Adamawa State in Maps Paraclete Publishers, Yola, Nigeria, pp 14-16.

USDA., 1997. Land Capability Classification, by State, 1997 Maps using data from the $1997 \mathrm{NRI}$, Revised December
Venkatatnam, L and Ravishankar, T., 2010. Remote Sensing and GIS Approach for land Productivity Assessment In proceeding volume of the interaction Symposium of ISPRS Commission VII on Resource and Environmental Monitoring held during December 3-6, 2002 XXXIV part 7: 256-261.

Vincent, L. A., Aguilar, E., Saindou, M., Hassane, A. F., Jumaux, G., Roy, D., Booneeady, P., Virasami, R., Randriamarolaza, L. Y. A., Faniriantsoa, F. R., Amelie, V., Seeward, H and Montfraix, B., 2009. Observed Trends in Indices of Daily and Extreme Temperature and Precipitation for the Countries of whe Western Indian Ocean, 19612008. Journal of Geophysical Research D: Atmospheres, 116(10). 